\title{
リバースステップ付きレイリーステップ端面シール*
}

\author{
池内健*1, 森美 郎*1, 西田徹*2
}

\section{A Rayleigh-Step Face Seal with Reverse Steps}

\author{
Ken IKEUCHI, Haruo MORI, and Tohru NISHIDA
}

\begin{abstract}
This paper presents a new hydrodynamic seal ; the pressure drops caused by the reverse steps reduce the hydrodynamic film force, while they scarcely affect the film stiffness if the steps are deep enough. Thus the clearance is controlled at high speed operation. The numerical analysis clarifies that the leakage flow rate of the seal is less than a critical value over the entire range of rotating velocities. The critical leakage flow rate which corresponds to a zero hydrodynamic film force condition is determined by the seal face design, and is independent of the balance ratio. If the seal operates at a relatively low balance ratio, the hydrodynamic lubricating film is formed from a low velocity, in addition, the leakage is limited at a high velocity. The experimental results confirm that a seal with reverse steps shows excellent performance over a wide range of rotating velocities.
\end{abstract}

Key Words : Machine Element, Lubrication, Seal, Rayleigh-Step, Reverse Step

\section{1. ま え がき}

過酷な条件下で高い信頼性と耐久性を要求される場 合に用いられるシュラウド付きレイリーステップシー $ル^{(1)(2)}$ は, 滑り面の加工が比較的容易で, 潤滑膜の剛 性が高い特長があるが, すきまが流体の粘度と回転速 度に依存する。したがって，もし低速時に十分なすき まを確保すれば高速時にすきまが過大となって漏れ量 が著しく多くなり, 逆に，もしバランス比を大きくし て高速時のすきまを制限すれば低速時および起動停止 時に摩擦と摩耗が著しくなる。したがって,この形式 のシールでは速度および密封流体の粘度の範囲が限定 され，特に作動中に回転速度が大きく変化する条件下 では安定した性能を発揮できない。

本論文では以上に述べた動圧非接触シールに特有の 欠点を除くため, シュラウド付きレイリーステップシ ールにリバースステップを設ける新しい形式の端面シ ールを提案し，その潤滑密封特性を調べた結果を報告 する.このシールでは高速回転時にリバースステップ

* 昭和 62 年 3 月 13 日 関西支部第 62 期定時総会請演会にお いて請演，原稿受付 昭和 61 年6月11日.

*1 正員，京都大学工学部 (冓606 京都方左京区吉田本町)

*2 正買, 川崎重工栄(怢) (西650-91 神戸市中央区中町通 2-118).
に生じる圧力降下を利用してすきまおよび漏れ量を制 限することにより，速度と粘度の広い範囲にわたって 安定した潤滑密封性能を発揮できる.

\section{2. 主 要記 号と添 字}

$$
\begin{aligned}
2 \cdot 1 & \text { 有次元量 } \\
f & : \text { 膜力 } \\
g_{i} & : \text { 半径方向みぞの深さ } \\
g_{r} & : \text { ポケット } 2 \text { (リバースステップ面 }) \text { の深さ } \\
g_{s} & : \text { ポケット } 1 \text { (ステップ面 }) \text { の樑さ } \\
h & : \text { すきま } \\
N & : \text { 毎分回転数 } \\
p & : \text { 圧力 } \\
p_{a} & : \text { 周囲圧力 } \\
p_{s} & : \text { シール差圧 } \\
q & : \text { 漏れ量 } \\
r_{i} & : \text { シールリングの内半径 } \\
r_{o} & : \text { シールリングの外半径 } \\
\mu & : \text { 流体の粘度 } \\
\omega & : \text { 軸の回転角速度 } \\
2 \cdot 2 & \text { 無次元量 } \\
F & : \text { 膜力 }=f /\left(p_{a} r_{o}^{2}\right) \\
G_{i} & : \text { 半径方向みぞの深さ }=g_{i} / r_{o}
\end{aligned}
$$


$G_{r}:$ リバースステップ面の深さ $=g_{r} / r_{0}$

$G_{s}:$ ステップ面の深さ $=g_{s} / r_{o}$

$H:$ すま $=h / r_{o}$

$K:$ バランス比

$P:$ 圧力 $=\left(p-p_{a}\right) / p_{a}$

$P_{s}:$ シ一ル差圧 $=p_{s} / p_{a}$

$Q:$ 漏孔量 $=q \mu /\left(p_{a} r_{o}^{3}\right)$

$a_{r}:$ 回転膜力係数

$\alpha_{s}:$ 静止膜力係数

$\beta_{r}:$ 回転漏九係数

$\beta_{s}:$ 静止漏孔係数

$\lambda:$ 軸速度 $=\mu \omega / p_{a}$

\section{$2 \cdot 3$ 添字}

$c: \alpha_{r}=0$ の状態

\section{3. リバースステップの作動原理}

図 1 に対象とするシール面の形状と滑り方向の膜厚 さの変化を示す. 高圧側 (密封流体側) に通じる深み ぞから滑り方向に向かって深さ $g_{s}$ のポケット1(ステ ップ面）が設けられ，その終端部は通常のレイリース テップと同様に機能し, 流体くさび効果によって潤滑 膜に負荷容量が生じ，その剛性が正となる。その下流 部には深き $g_{r}$ のポケット2（リバースステップ面）が 設けられ，次の深みぞに通じている、リバースステッ プでは滑り方向に膜厚が増加するので，この部分のみ を考えると流体くさび効果による負荷容量および潤滑 膜剛性は負である，ただし，一般にシールにおいては 大きい負荷容量は必ずしも必要でなく，むしろバラン ス比を小さくして軽負荷で作動させることによって起 動を容易にし，摩耗を減らすことができる、また $g_{r}$ を $g_{s}$ より十分に大きくすれば，リバースステップでの圧 力降下はすきまの変化にあまり影響されないので潤滑 膜全体の剛性はリバースステップによってほとんど低 下しない.したがって,リバースステップに生じる負

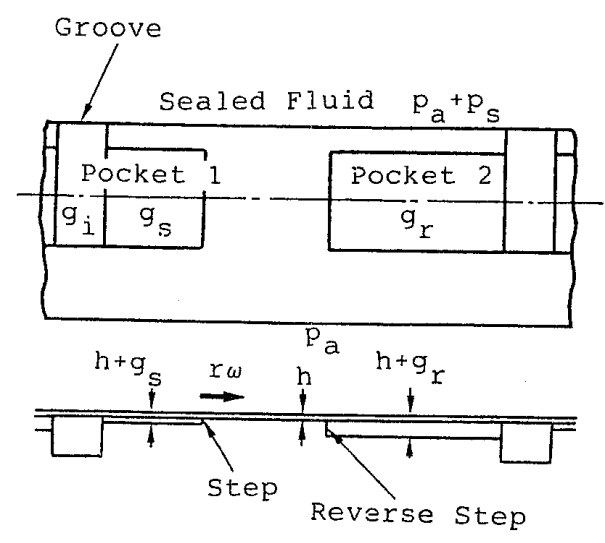

図 1 シール面の概念図
の顀荷容量を利用して高速回転時にすきまが過大とな るのを防ぐことにより，広い速度範囲にわたってすき まと漏れ量を適当な範囲に保つことができる。

\section{4. 理 論 解 析}

すきま内の流体は等粘度, 非圧縮性の粘性流で，流 体膜が破断しないと仮定すると，次のレイノルズ方程 式が成立する。

$$
\begin{aligned}
& \frac{\partial}{\partial r}\left(r h_{l}^{3} \frac{\partial p}{\partial r}\right)+\frac{1}{r} \frac{\partial}{\partial \theta}\left(h_{l}^{3} \frac{\partial p}{\partial \theta}\right) \\
& =6 \mu \omega \frac{\partial h_{l}}{\partial \theta}
\end{aligned}
$$

ここで $p$ は圧力, $h$ は膜厚さ， $\mu$ は粘度， $\omega$ は回転角 速度である. 密封流体側 $\left(r=r_{0}\right)$ の圧力を $p_{a}+p_{s}$, 低圧 側 $\left(r=r_{i}\right)$ の圧力を $p_{a}$ として式(1)を $p$ について解 くと, 膜力 $f$ と漏れ量 $q$ を次式より計算できる.

$$
\begin{aligned}
& f=\int_{0}^{2 \pi} \int_{r_{i}}^{r_{0}}\left(p-p_{a}\right) r d r d \theta \\
& q=\frac{r}{12 \mu} \int_{0}^{2 \pi} h_{l}^{3} \frac{\partial p}{\partial r} d \theta \quad \ldots . .
\end{aligned}
$$

$h \iota$ の最小值（以下ではすきまと呼ぶ）を $h$ と表示し, 無次元軸速度を $\lambda=\mu \omega / p_{a}$ と定義する. 他の無次元量 の定義式は $H=h / r_{o}, G=g / r_{o}, P=\left(p-p_{a}\right) / p_{a}, F=f /$ $\left(p_{a} r_{o}^{2}\right), Q=q \mu /\left(p_{a} r_{o}^{3}\right)$ である.

数值計算においてはシール面の一単位を半径方向に 12 分割, 円周方向に 32 分割し, $H$ を与えてダイバー ジェンスフォーミュレーション (3)(4)を用いた。 式(1) は $P$ およ゙ $\mu \omega に$ 関して線形であるから， $p_{s}, \lambda$ のす べてについて計算する必要はなく, $p_{s}=0$ および $\lambda=0$ の計算結果から

$$
\begin{aligned}
& F=\alpha_{s} P_{s}+\alpha_{r} \lambda \\
& Q=\beta_{s} P_{s}+\beta_{r} \lambda
\end{aligned}
$$

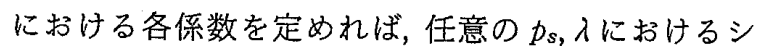
ール特性を知ることができる.以下では $\alpha_{s}$ を静止膜力

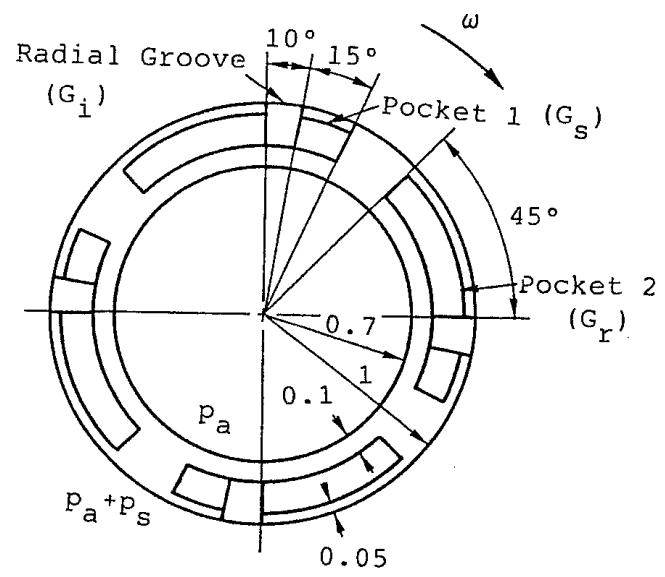

図 2 シールリングの形状 
係数, $\alpha_{r}$ を回転膜力係数, $\beta_{s}$ を静止漏れ係数, $\beta_{r}$ を 回転漏れ係数と呼ぶ.

\section{5. 計算結果の考察}

図 2 に計算の対象としたシール面の形状を示す。シ ール面には円周方向に $90^{\circ}$ ごとに 4 組のステップがあ る.

表1に各ポケットの無次元樑さを示す.

計算によれば静止膜力係数 $\alpha_{s}$ はすきま $H$ にほとん ど無関係であり，静圧効果は潤滑膜の剛性に寄与しな い.

図 $3 に H$ と回転膜力係数 $\alpha_{r}$ の関係を示す. $G_{r}$ が 小さいほど $\alpha_{r}$ は小さく, シールCでは $H$ が $0.593 \times$ $10^{-3}$ より大きいと $\alpha_{r}$ 媍となる. 同じ $H$ においてシ ール A, B, Cの各曲線の傾きはほほ等しく, リバース ステップによって潤滑膜の剛性はあまり低下していな い. しかし $G_{r}$ の小さいシールDにおいては, $H$ が $0.27 \times 10^{-3}$ より大きいと $\alpha_{r}$ が $H$ の増加関数となっ ており，この部分では剛性は負である。すなわち $G_{r}$ を $G_{s}$ より十分に大きくしなければ安定した流体膜を 形成できない.

图 4 に示すように, $H$ が大きくなると静止漏れ係数 $\beta_{s}$ が急激に増加するので, $H$ を制限することが必要 である.リバースステップのあるほうが $\beta_{s}$ が少し大

表 1 ステップ面の無次元哚さ

\begin{tabular}{c|c|c|c}
\hline \hline シールリング & $G_{s}$ & $G_{r}$ & $G_{r} / G_{s}$ \\
\hline $\mathrm{A}$ & 0.001 & 0 & 0 \\
\hline $\mathrm{B}$ & 0.001 & 0.01 & 10 \\
\hline $\mathrm{C}$ & 0.001 & 0.005 & 5 \\
\hline $\mathrm{D}$ & 0.001 & 0.0025 & 2.5 \\
\hline
\end{tabular}

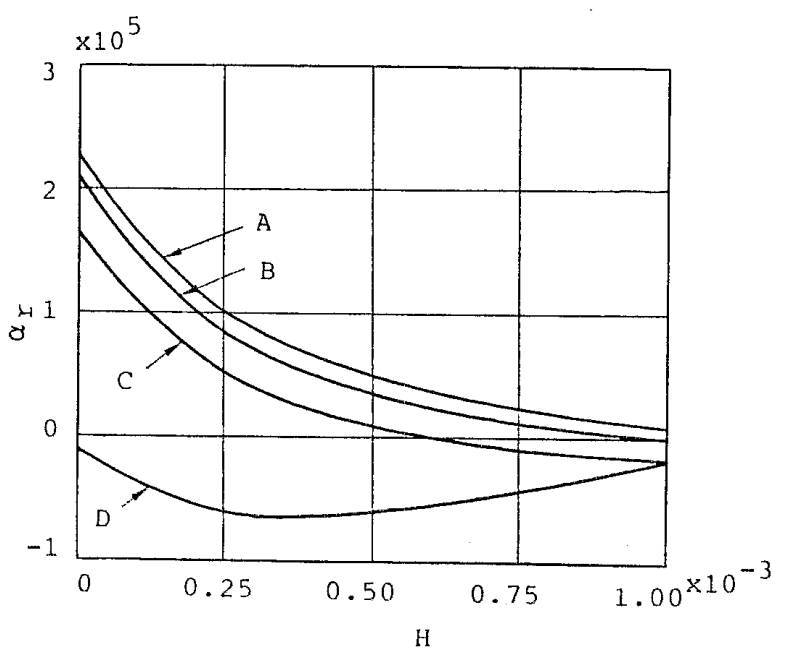

図 3 回転膜力係数
きいが, $G_{r}$ の影響はほとんど見られない.

なお $\beta r$ はきわめて小さく，このシールではポンピ ング作用は見られない.

つぎにリバースステップのないシール A とリバー スステップが最も有効に機能するシールCについて, $p_{s}$ が一定で入が変化する場合のすきまと漏れ量の変 化を示す. 図 5 はシール A における $\lambda$ と $H$ の関係で ある。

$$
K=f /\left\{\pi\left(r_{0}^{2}-r_{i}^{2}\right) p_{s}\right\}
$$

で定義されるバランス比が大きいほど $H$ がたちあが る点の入の值が大きく, 流体膜が形成された後の $H$ の值が小さい.

図 6 はシールCにおける $\lambda$ と $H$ の関係である. $K$ $=0.815$ の場合には $H$ は $\lambda$ に無関係に一定值 $0.593 \times$ $10^{-3}$ である.このときには $\alpha_{r}=0$ であり，流体くさび 効果によって負荷容量は生じていない，以下ではこの 状態を添字 $c$ で表示する. $K$ が 0.832 より大きい場合

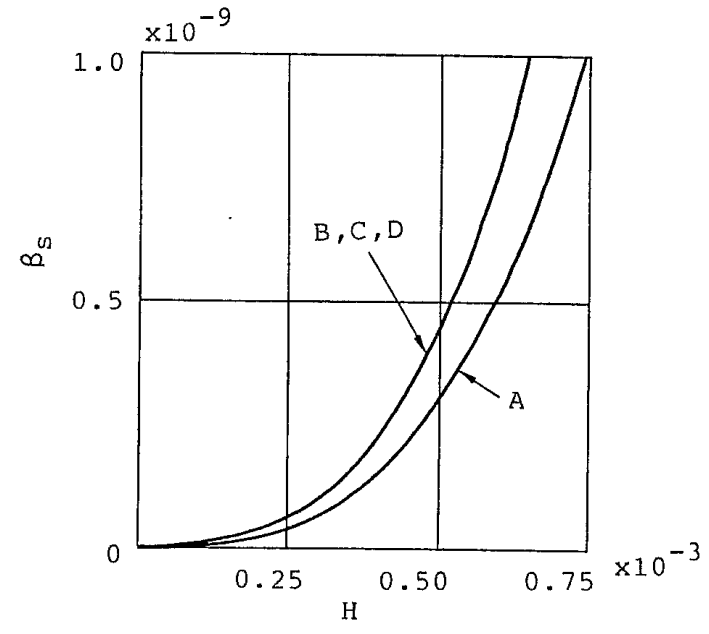

図 4 静止漏れ係数

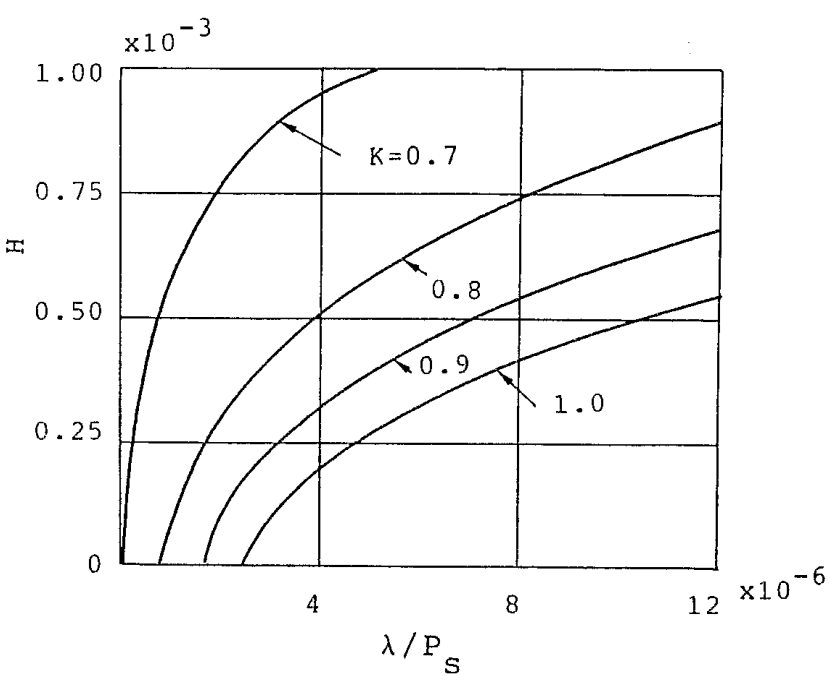

図 5 リバースステップのないシールのすきま 
には, $\lambda$ が小さいと二面は接触しているが，入の增加 とともに $H$ が増加して $H_{c}$ に溸近する. $K_{c}<K<$

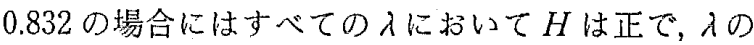

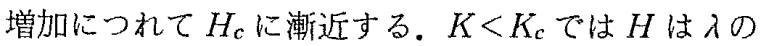
減少関数であるが,この条件でシールを作動させるこ とはないだろう。

図 7 はシールAに打ける入と漏机量 $Q$ の関係であ る. $\lambda$ が増加するとQ $Q$ が急激に增加している.

図 8 はシールCに拈ける入と $Q$ の関係である. $K$

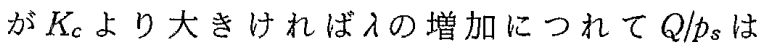
$0.737 \times 10^{-9}$ に近づくが，これを超えることはない． $Q_{c}$ の值はシールの面の形状のみによって決まるので, 流体の粘度が極端に低下しないかぎり漏れ量の最大值 をあらかじ知ることができ，たとえば漏れた流体を 回収するポンプの容量を容易に見積もることができ る。

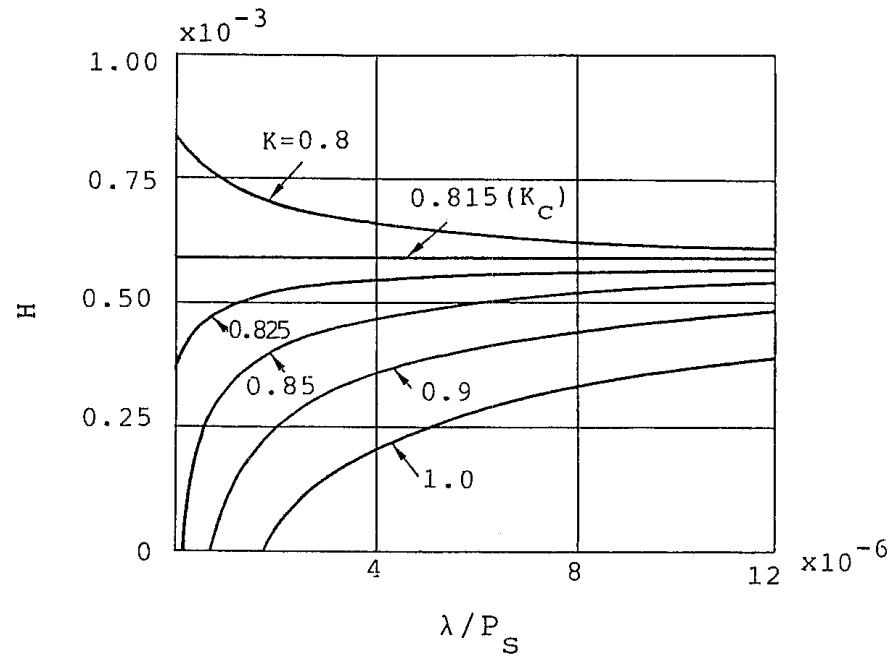

図 6 シールCのすきま

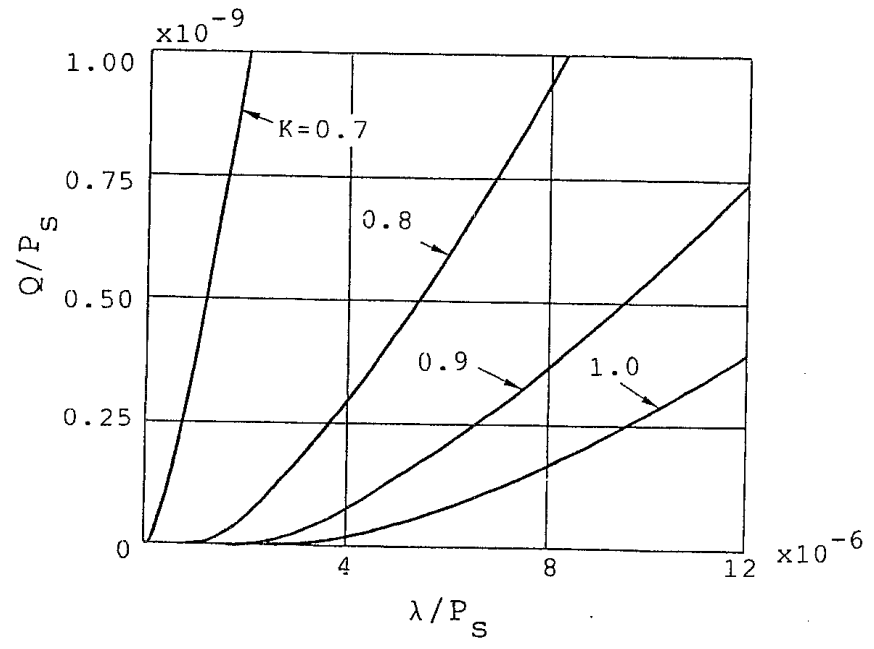

図 7 リバースステップのないシールの漏れ量

\section{6. 実験装置と弚の方法}

図 9 に実験装置の概要を示す．静圧空気軸受で支え られた回転軸の端面には図 2 で示したのと同一形状の ステップを加工された回転シールリングが固定されて いる。回転シールリングの外径は $80 \mathrm{~mm}$ ，内径は 56 $\mathrm{mm}$ であり, $r_{i} / r_{0}=0.7$ である.各シールリングのポケ ット深さは表 2 に示すと扔りで, 数值計算を行った表 1 と対応している. 半径方向みぞの深さ $g_{i}$ は $1 \mathrm{~mm} て ゙$ ある。

各シール面を直径 $3 \mathrm{~mm}$ のエンドミルで加エした 後, 平面研削によって $g_{s}=40 \mu \mathrm{m}$ になるように調整し た。ポケット内の表面粗さのため, $g_{s}$ は 36〜 $45 \mu \mathrm{m}$ の 間にあった，回転シールリングの材質は鋼 (S $55 \mathrm{C}$ ) で あり，静止シールリングの材質は黄銅（BsBM 2)であ る.

軸は $400 \mathrm{~W}$ の可変速電動機（定格トルク $3.2 \mathrm{Nm}$ ) により V ベルトで2 倍に増速されて駆動される。密封 流体は $20^{\circ} \mathrm{C} て ゙ 0.0183 \mathrm{~Pa} \cdot \mathrm{s}$ の鉱油である.

シールリングの押し付け力を減らすため, 図 9 に示 す外径 $2 r_{o}$, 内径 $2 r_{i}$ の空気室に圧力 $p_{b}$ を加元て密封 圧力による押し付け力と逆方向に軸を押す。この場合 には式 (6)で定義されたバランス比を

$$
K=\left(p_{s}-p_{b}\right) / p_{s}
$$

表 2 ステップ面の梁さ

\begin{tabular}{c|c|c|c}
\hline \hline シールリング & $g_{s}, \mu \mathrm{m}$ & $g_{r}, \mu \mathrm{m}$ & $g_{r} / g_{s}$ \\
\hline $\mathrm{A}$ & 40 & 0 & 0 \\
\hline $\mathrm{B}$ & 40 & 400 & 10 \\
\hline $\mathrm{C}$ & 40 & 200 & 5 \\
\hline
\end{tabular}

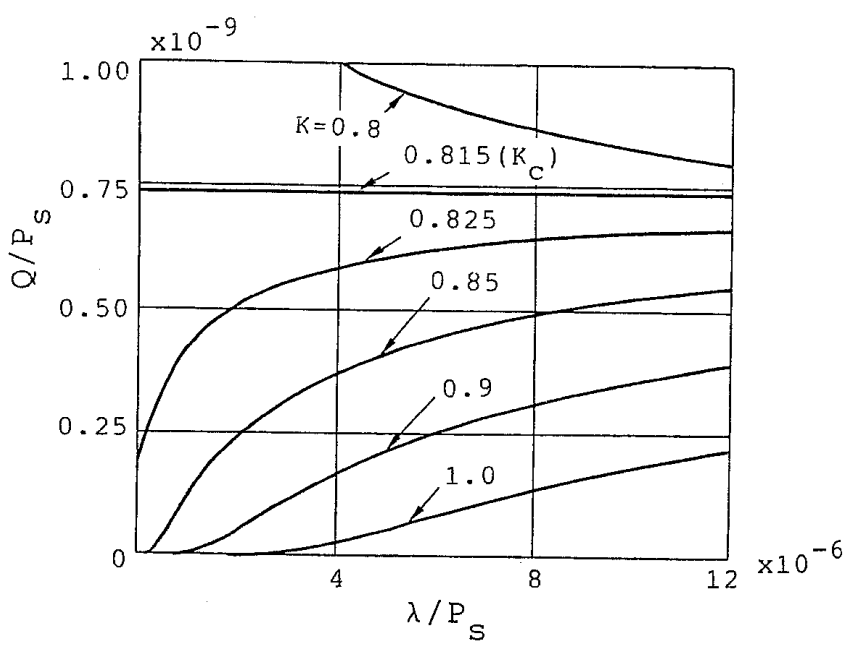

図 8 シールCの漏れ量 


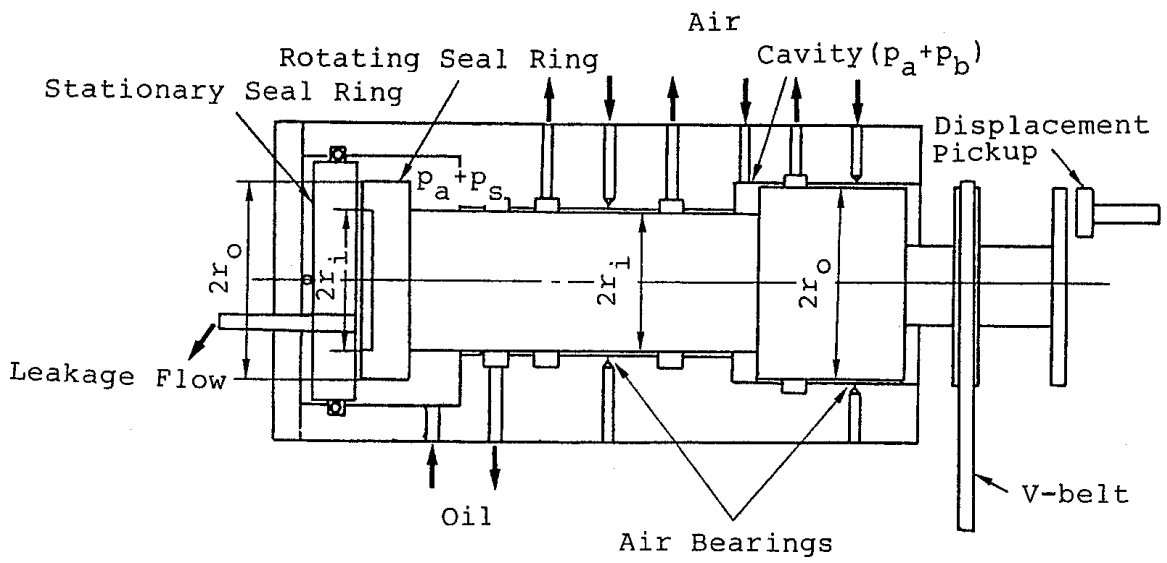

図 9 実験装置

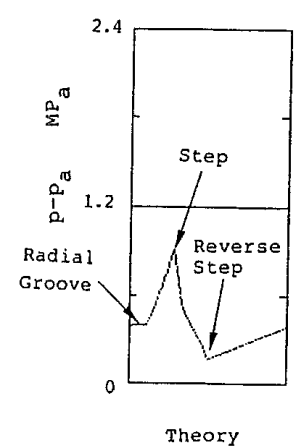

(a) $K=0.825$

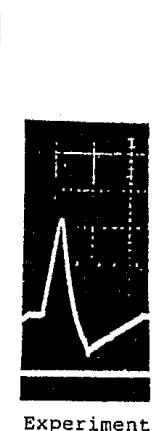

Experiment

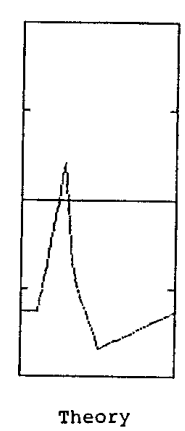

(b) $K=0.925$

図 10 円周方向の压力分布 (シールC)

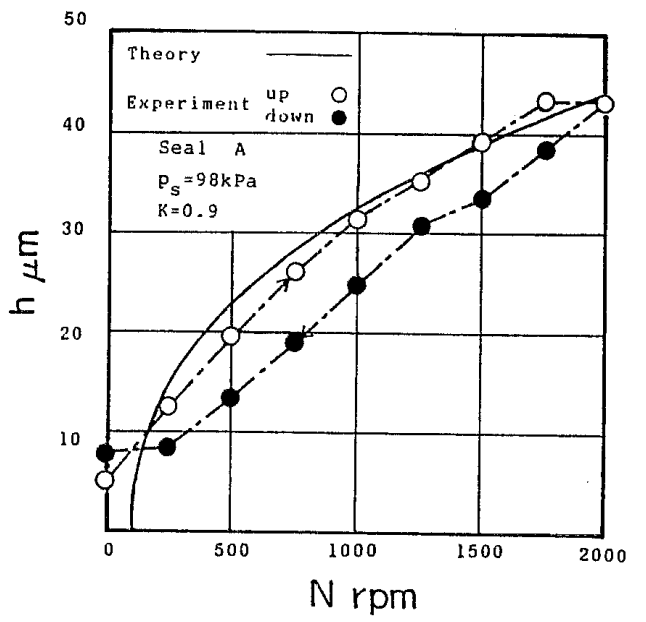

図 11 リバースステップのないシールのすきま

\section{としたのと力学的に等価である.}

すきまの測定にあたって、軸の熱膨張の影㪷を避け るため, 測定後静止させて $p_{b}=0$ とした時の軸位置を 接触状態 $(h=0)$ と見なした。滁机量はメスシリンダで 測定した。シールリングの近くにCu-Co 熱電対を犆い て漏孔た直嗳の油温を测定し、これを潤滑膜の温度と 見なした。

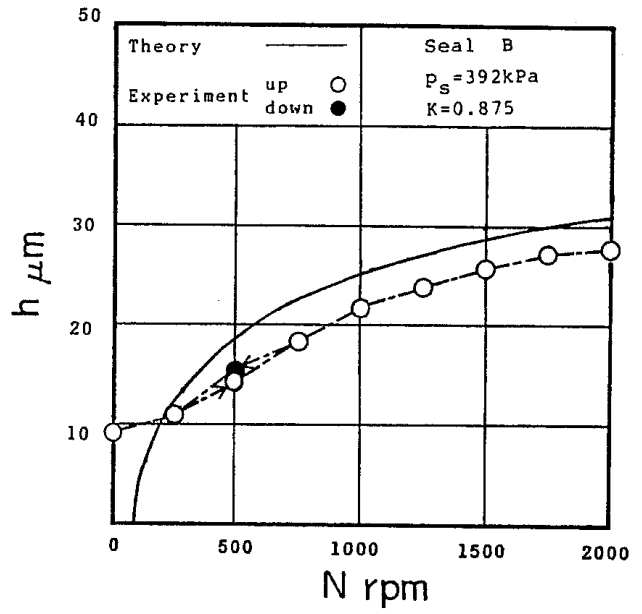

図 12 シールBのすきま

\section{7. 実験結果と考察}

実験は $p_{s}=392 \mathrm{kPa}$ で行ったが，リバースステップ のないシール A では，Kを大きくすると起動トルク が大きいため回転せず， $K$ を小さくすると回転速度の 増加につれて漏九量がきわめて多くなり，0〜2000 $\mathrm{rpm}$ の範囲で正常に作動させることができなかった ので, シール A みみ $p_{s}=98 \mathrm{kPa}$ とした.

図 10 はシールCを $p_{s}=392 \mathrm{kPa}, N=1000 \mathrm{rpm}$ で 作動させたときの $r=37 \mathrm{~mm}\left(r / r_{o}=0.925\right)$ の位置に おける円周方向の圧力分布を静止シールリング上の直 径 $0.8 \mathrm{~mm}$ の測定孔により測定したものである. 圧力 は深みぞ位置から回転方向に上昇し，ステップ位置で 最大となった後降下し、リバースステップ位置で最小 となり，次の樑みぞまでほぼ直線的に上昇する，図 10(a)よりもKの大きい図 10（b）のほうがステップ の圧力が高いが、リバースステップでの圧力降下量は ほとんど变わらない. 図 10 より、シールリングに加わ る押し付け力が増加して $h$ が小さくなると，ステッブ 
での圧力が上昇して外力と釣り合うことにより，安定

した流体膜を維持できることがわかる。

図 11 はシールAに㭁ける毎分回転数 $N$ とすきま hの関係である。Nの增加につれて $h$ は大きくなり， $N=2000 \mathrm{rpm}$ では $h$ は $40 \mu \mathrm{m}$ を超えている.

図 12 はリバースステップ面の深いシール B の場合 である. 理論上図 11 と同じ $100 \mathrm{rpm}$ で二面が離れる

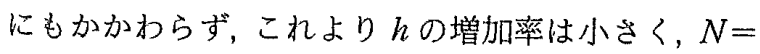
$2000 \mathrm{rpm}$ で $h$ は $30 \mu \mathrm{m}$ 程度にとどまる。

図 13 はシールCにおける $N$ とhの関係で, $N=40$ rpmですきまが形成されるように $K$ を決めると $h$ が $20 \mu \mathrm{m}$ 以下にとどまることが示されている.

図 14 はシールCにおいて $K$ を小さくして理論上 常に非接触状態を保つようにした場合である. $N$ の増 加につれて $h$ は增加するが, $h_{c}=23.7 \mu \mathrm{m}$ に渐近し, これ以上になることはない。なおる, 静止状態で理論值 と実験值がかなり異なっているのは，潤滑膜の剛性が きわめて低いため，安定したすきまを形成できないこ

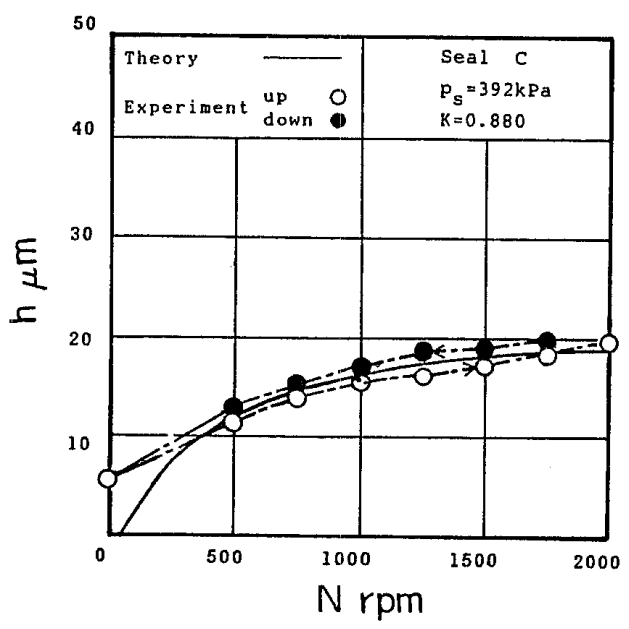

図 13 シールCのすきま

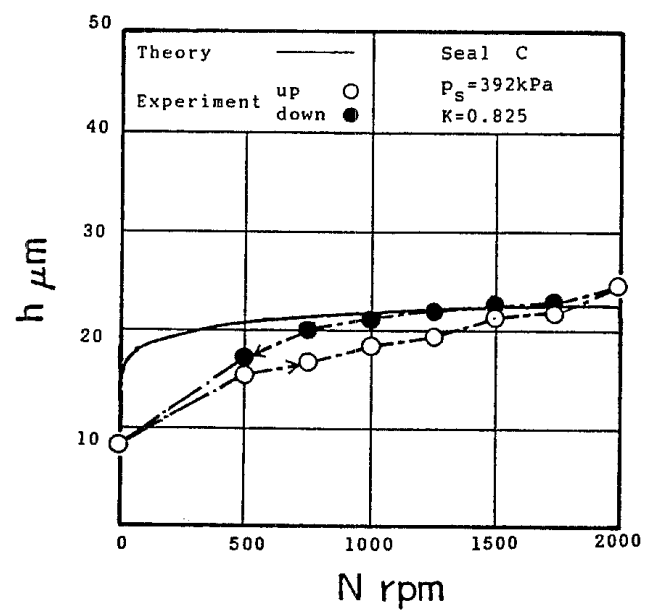

図 14 シールCのすきま
とによると思われる。

漏れ量の測定にはかなりの時間を要したので，温度 変化を無視できなかった．したがって以下の図面にお ける理論值として，各測定時の温度に対応した值を示

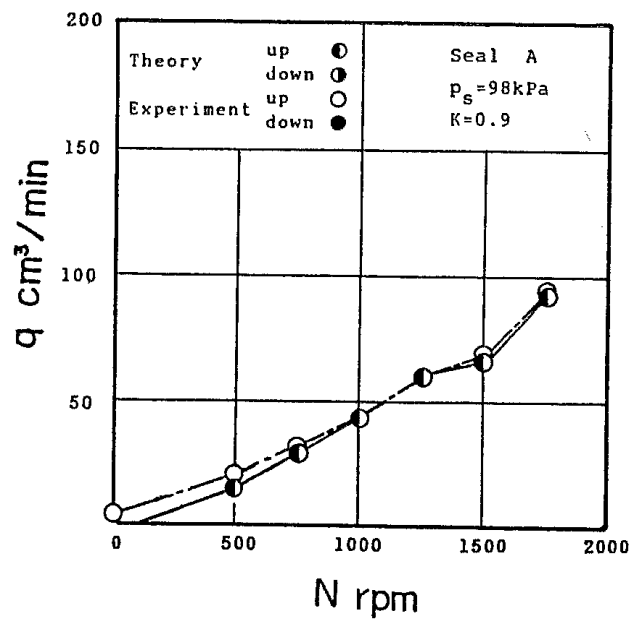

図 15 リバースステップのないシールの漏れ量

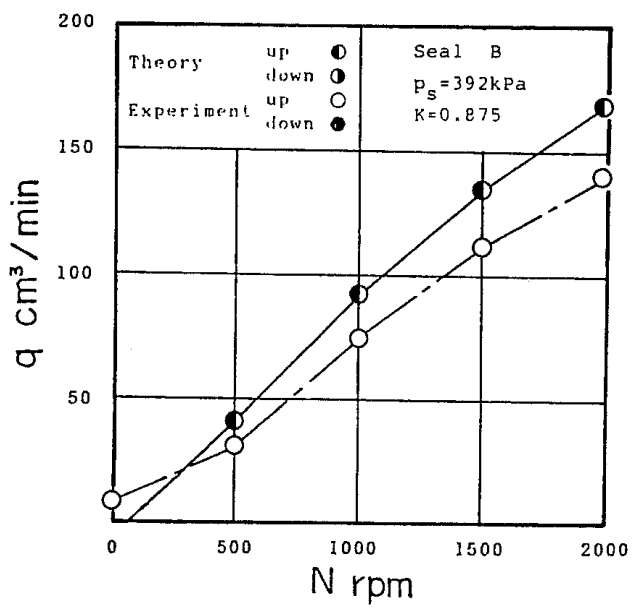

図 16 シール B の漏れ量

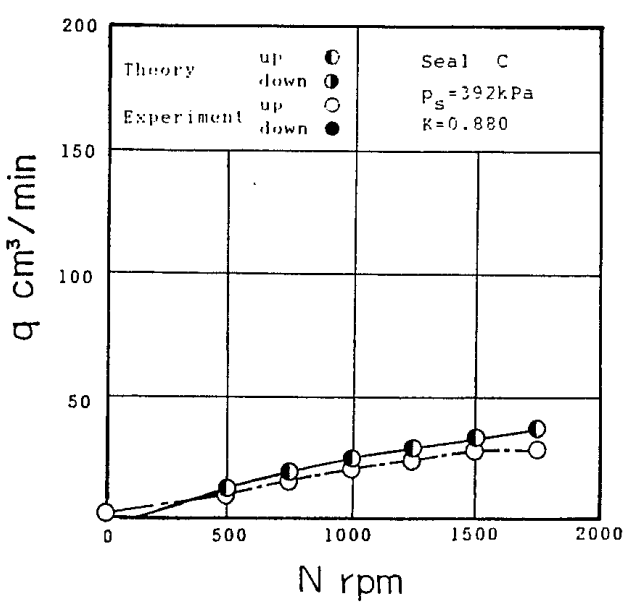

図 17 シールCの漏れ量 


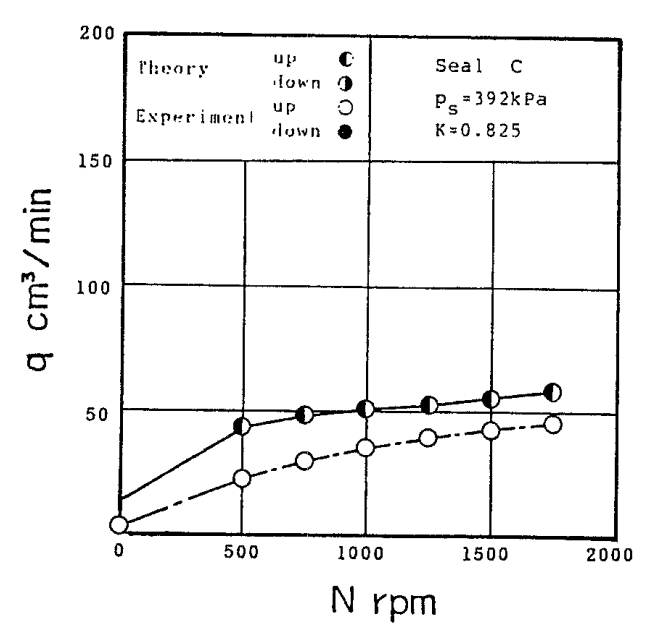

図 18 シールCの漏れ量

す.

図 15 はシールAにおける $N$ と毎分漏れ量 $q$ の関 係である. $N$ が増加すると $q$ が急激に増加している。

図 16 はシール Bにおける $N$ と $q$ の関係である. $N$ と $q$ はほほ比例関係にある。この場合にはリバースス テップが深すぎて十分に機能していないと言えるだろ う.

図 17 はシールCを図 13 と同じバランス比で作動 させた場合の $N$ とqの関係である. 全速度範囲を通 じて $q$ は $40 \mathrm{~cm}^{3} / \mathrm{min}$ 以下であり,リバースステップ が有効に機能していることが示されている。

図 18 はシールC を図 14 と同じバランス比で作動 させた場合で, 理論上, 全速度範囲で非接触状態が保 たれる小さなバランス比であるにもかかわらず，リバ 一スステップの効果によって漏机量が一定值以下に制 限されている.

\section{8. ま と め}

レイリーステップシールが広い速度範囲で安定した 性能を発揮できない欠点を補うため,これにリバース ステップを付けることを試みた.リバースステップ面 が浅すぎると潤滑膜の剛性が低下し，逆に深すぎると 有効に機能しないことが明らかになった。またリバ ースステップ付きシールにおいては，特にバランス比 をシール面の形状に応じて正確に決めなければならな いことがわかった．以上のことを考慮して適切に設計 されたリバースステップ付きシールは次のようなすぐ れた性能を発揮することが期待される。

（1）軸の回転開始後, 容易に流体潤滑状態となり, 低速でも安定したすきまを維持できる.

（2）回転速度に対するすきまの変化率は小さく， すきまはシール面の形状によって決まる一定值を超え ない.

（3）回転速度に対する漏れ量の変化率は小さく, 高速回転時に温度上昇によって粘度が極端に低下しな いかぎり，漏れ量はシール面の形状によって決まる一 定值以下に保たれる。

最後に, 実験に助力された, 当時京都大学学生の田 村讓, 村井保信の両氏に感謝する.

\section{文献}

(1) Walowit, J. A. and Pinkus, O., Trans. ASME, J. Lubr. Technol., 104-2 (1982), 262.

(2) Artiles, A., ほか 2 名, ASLE Trans., 27-4 (1984), 321.

(3) Castelli, V. and Pirvics, J., Trans. ASME, Ser. F., 884 (1968), 777.

（4）金子, 潤滑, 29-9 (昭 59), 633 .

\section{討 論}

\section{〔質問〕矢 部 寛〔京都大学工学部〕}

貴研究で提案されているシールは，簡明な機構でし かもきわめて興味深い特性を示し，大変扔もしろく感 じた.

次の点について扔同いしたい。

（1）貴論文では，ポケット1，2（リバースステッ プ部）の周方向の比率の影響については言及しておら れないが, 図 2 の形状がほぼ推奨される值になってい ると考えてよいか。

（2）シール面に占めるリバースポケットの面積比 率の割合が大きいので，シール面減衰係数は低下する と思う。実用上の問題はないと考えてよいか。
〔回答〕（1）順ステップによる潤滑膜の剛性が 高いすきま条件においてりバースステップによる剛性 の低下を最小限に留めるためには $g_{s}$ に比べて $g_{r}$ を十 分に大きくする必要があり，この場合にリバースステ ップに生じる負の負荷容量がすきまの調節に有効に作 用するためにはリバースステップ面の面積を順ステッ プ面より大きくする必要がある。リバースステップを 用いる目的は，特定の作動状態での性能を最高にする のではなく、できる限り広い作動範囲で閏滑性と密封 性を雨立されることにあるので, 澱密な意味での最適 化は困難だが、寸法を変えた数值解析の経駼から, 通 常の条件では図 2 に示す形状が推奨值に近いと思う。 
（2）リバースステップのポケット部は深いので, ご指摘のようにこの部分は潤滑膜の減衰性にほとんど 貢献しないと思う。少なくとも液体を用いる限り実用 上問題はないと思うが，特に高い減衰性を要求される 場合には，設計上，両ステップ間の平たんな部分の面 積を大きくすることによって対処することが可能であ る。な扔, 本シールでは各圧力発生部が独立して機能 するので流体力学的不安定現象としての円すいモード のふれまわり(付1)は生じないはずである。

[質問]中原綱 光〔東京工業大学工学部] 従来のレイリーステップシールの改良に静圧軸受に おける表面絞りの原理を巧妙に応用した点が大変興味 深い。その作動範囲に関してお伺いしたい。

（1）条件によっては，リバースステップに扔いて 大気压以下になり，貴論文のように作動流体を液体と した場合にはキャビテーションの発生が考えられる が，その可能性についてはいかがか。

（2）もしキャビテーションが発生する場合には， その影響はどのように現れると考えられるか。

〔回答〕（1） $\lambda / P_{s}$ のきわめて大きい作動条件 では理論上リバースステップ部の圧力が周囲圧力以下 になるが,この場合にはキャビテーションが生じる可 能性が高いと考えている。

（2）キャビテーションが生じるとりバースステッ プ部の圧力が上昇するので $H$ および $Q$ が増加し，こ れによってリバースステップの作動限界が現れると思 う.したがって,リバースステップ部の圧力を常に周 囲圧力以上に保ち，たとえ気泡が析出しても半径方向 の圧力こう配によって低圧側へ流れるようにシールを 設計すべきであろう。

〔質問〕金子礼三

[日本電信電話(株)電子機構技術研究所]

スライダに負圧発生部分を設け, 浮上がり量を制御 することは，磁気記録用の浮動へッドスライダにおい て試みられているが, 浮上がり量制御をさらに流量制 御にまで進め，もれ量の少ない非接触シールを提案さ れたことに敬意を表する。論文を拝見すると，実験デ 一夕に理論と若干の差が見られるが, その解釈につい
て㭁伺いしたい.

（1）すきまと回転数の関係を示す図 11〜14にお いて，回転数増と隇ですきまにヒステリシスを生じて いるデー夕が散見されるが，測定上の単なる誤差なの か，もしくは油の挙動になんらかの差異があると考え られるのか。

（2）同じく図 11〜14において，静圧状態で若干 のすきまが観測されているが，これは完全に停止する 直前（回転数 $\rightarrow 0 ）$ のデータか.このとき安定したす きま形成ができないと述べられているが，すきまが動 的に不安定な現象を観測されたのか。卆とも，滑り 面のう放り・微小すきまでの粘度変化など他の要因で 想定されるのか.

【回答】非接触シールと磁気記録用浮動ヘッドス ライダは全く異なった目的に用いられるにもかかわら ず，できる限り低速から流体膜が形成され，しかもす きまが過大にならないことが要求され，また負荷容量 の大きさは重要でない反面, 潤滑膜の剛性の高い必要 であるなど共通点が多く見られるのは興味深いと思 3 .

（1）リバースステップのない図 11 の場合に減速 時のほうがすきまが小さい理由は温度上昇により油の 粘度が低下したためと推定している.リバースステッ プのある場合に逆に増速時のすきまがわずかに小さい のは，この場合にはすきまの粘度依存性が少ないため， これに代わって熱変形の影暜が現れたのかもしれな い.

（2） $N=0$ に対応する実験值は回転前および停止 後の值である. 静止状態のすきまについて議論した図 14 の場合は，理論上 $16 \mu \mathrm{m}$ のすきまが存在するにも かかわらず，実際には静圧効果による潤滑膜魝性がき わめて低いので安定したすきまを形成することができ ず，2 面が接触状態となって $h$ が $8 \mu \mathrm{m}$ になったと考 えている.なお，接触状態において $h$ が 0 にならない のは，2 面が完全な平面でないので，正のすきまを維 持したまま部分的に接触するためであると思う。

(付 1) Green, I. and Etsion, I., ASLE Tran., 28-4 (1985), 449. 